\title{
Longitudinal monitoring of SARS-CoV-2-specific immune responses
}

\author{
Heike Rebholz ${ }^{1,2,3, \#}$, Ralf J. Braun ${ }^{1, \#, *}$, Titas Saha ${ }^{4}$, Oliver Harzer ${ }^{5,6}$, Miriam Schneider ${ }^{4}$, and \\ Dennis Ladage ${ }^{7,8,9^{*}}$
}

${ }^{1}$ Research Department for Neurodegenerative Diseases, School of Medicine, Danube Private University, Krems/Donau, Austria; ${ }^{2}$ Institut de Psychiatrie et Neurosciences de Paris (IPNP), UMR S1266, INSERM, Université de Paris, Paris, France; ${ }^{3} \mathrm{GHU}$ Psychiatrie et Neurosciences, Paris, France; ${ }^{4}$ Department of Scientific Coordination and Management, Danube Private University, Krems/Donau, Austria; ${ }^{5}$ Center of Biosciences, Danube Private University, Krems/Donau, Austria; ${ }^{6}$ Bioscientia, Institute of Medical Diagnostics, Ingelheim, Germany; ${ }^{7}$ Department of Internal Medicine, Danube Private University, Krems/Donau, Austria; ${ }^{8}$ Heart Center, University of Cologne, Germany; ${ }^{9}$ Department of Pneumology, Maria Hilf Hospital, Mönchengladbach, Germany

\#Equally contributing authors

*Corresponding authors: ralf.braun@dp-uni.ac.at; dennis.ladage@dp-uni.ac.at

\section{Running title}

Monitoring SARS-CoV-2 immune responses

\section{Key words}

COVID-19, SARS-CoV-2, serology, IgA, IgG, immunoglobulin, antibody response, $\mathrm{T}$ cell response, antibody persistence, immune response 
medRxiv preprint doi: https://doi.org/10.1101/2021.08.14.21262042; this version posted August 20, 2021. The copyright holder for this preprint

\begin{abstract}
The Lower Austrian Wachau region was an early COVID-19 hotspot of infection. As previously reported, in June 2020, after the first peak of infections, we determined that $8.5 \%$ and $9.0 \%$ of the participants in Weißenkirchen and surrounding communities in the Wachau region were positive for SARS-CoV-2-specific immunoglobulin $\mathrm{G}(\mathrm{IgG})$ and immunoglobulin A (IgA) antibodies, respectively. Here, we present novel data obtained eight months later (February 2021) from Weißenkirchen, after the second peak of infection, with 25.0\% (138/552) and 23.6\% (130/552) of participants that are positive for IgG and IgA, respectively. In participants with previous IgG/IgA positivity (June 2020), we observed a $24 \%$ reduction in IgG levels, whereas the IgA levels remained stable in February 2021. This subgroup was further analyzed for SARS-CoV-2-induced $\mathrm{T}$ cell activities. Although 76\% (34/45) and 76\% (34/45) of IgG positive and IgA positive participants, respectively, showed specific T cell activities, those were not significantly correlated with the levels of $\operatorname{IgG}$ or IgA. Thus, the analyses of antibodies cannot surrogate the measurement of $\mathrm{T}$ cell activities. For a comprehensive view on SARS-CoV-2-triggered immune responses, the measurement of different classes of antibodies should be complemented with the determination of T cell activities.
\end{abstract}

\title{
Introduction
}

SARS-CoV-2 infections lead to an adaptive immune response that comprises the participation of virus-specific antibodies of immunoglobulins $\operatorname{IgM}, \operatorname{IgG}$, and $\operatorname{IgA}$, as well as cellular responses by various $\mathrm{T}$ cell species and other immune cells (1). IgGs are most prevalent in serum, making up approximately $75 \%$ of all serum antibodies and are known to be important at later stages of immunity (1). IgAs are found in serum as well but can also be secreted in high levels into mucosal surfaces, where they play important roles as first line of defense of the adaptive immune system against viral infections $(2,3)$.

Many studies on the persistence of antibodies exist for SARS-CoV-2 infections (1-17), but data are still controversial and data informing on the timeline beyond six months are still rare, taking into account the short existence of the pandemic (18). Nevertheless, positive IgG and IgA results were reported for up to eight months (reviewed in (18)). Prior experience with other human coronavirus species suggests that antibody-based immunity may last for twelve months or more (19).

Various $\mathrm{T}$ cell types compose the cellular immune response and are key to protective immunity against COVID-19 (20). T cells are a heterogeneous group of immune cells, which, among others, can trigger cell death in virus-infected cells. Both $\mathrm{CD} 4+$ and $\mathrm{CD} 8+\mathrm{T}$ cells can develop into 
medRxiv preprint doi: https://doi.org/10.1101/2021.08.14.21262042; this version posted August 20, 2021. The copyright holder for this preprint

memory cells, thereby critically adding to long-lasting immunity. In SARS-CoV-2 infections, the current paradigm states that the T cell-based immune response precedes antibody-based immune responses (21). Lack of sufficient $\mathrm{T}$ cell-based immune responses may cause severe COVID-19 progression $(21,22)$, and low peripheral $\mathrm{T}$ cell counts were associated with non-survival (22), while an early $\mathrm{T}$ cell response was linked to a milder form of COVID-19 $(23,24)$. $\mathrm{T}$ cell response magnitude was significantly higher in patients recovering from severe disease than in patients with mild cases (25). Thus, SARS-CoV-2-specific T cell activity is critically linked with the clinical course of the disease.

Considering the importance of IgG, IgA and T cells for the immune response to SARS-CoV-2, we determined 1) IgG and IgA seropositivity, titer levels and persistence and 2) interferon $\gamma$ release (IGRA) as a readout of $\mathrm{T}$ cell activity in a sample of 552 inhabitants of Weißenkirchen, Austria.

\section{Methods}

Venous blood from 552 participants was collected on the 13th of February 2021 by members of the Lower Austrian Red Cross. Research subjects had to be inhabitants of Weißenkirchen, Austria, to be eligible for enrollment. The cohort consisted of non-infected participants, formerly infected but recovered, and potentially acutely infected but asymptomatic cases. Participants were questioned about a prior SARS-CoV-2 infection as well as prior SARS-CoV-2 specific PCR or antigenic tests and their outcomes. Participants were questioned about medical preconditions, previous disease symptoms, including SARS-CoV-2 specific symptoms (e.g., fever, cough and respiratory problems, cold, olfactory dysfunction). Some subjects had already participated at previous data collections $(26,27)$.

Serum samples were analyzed by a certified diagnostic laboratory (Bioscientia, Ingelheim, Germany) with an EC-certified semiquantitative enzyme-linked immunosorbent assay (Euroimmun AG, Lübeck, Germany), for the determination of serum levels of IgG and IgA antibodies, specific for the receptor binding domain of the SARS-CoV-2 (S) spike protein (26). Serum from a sub-cohort of participants, who had tested positive for $\operatorname{IgA}$ or $\operatorname{IgG}$ at a previous data collection in June 2020 or presented documentation of a previous SARS-CoV-2 infection, was also used for measurement of $\mathrm{T}$ cell activity. Interferon-gamma (IFN- $\gamma$ ) release assay (IGRA) is an in vitro blood diagnostic test used in clinical laboratories to measure IFN- $\gamma$ released by antigen-specific T-cells. In this assay, isolated T cells are incubated overnight with a peptide mix specific to the SARS-CoV-2 spike protein. The release of interferon $\gamma$ by activated $\mathrm{T}$ cells was measured in an ELISA system (interferon $\gamma$ release assay, IGRA) according to the protocol of the 
medRxiv preprint doi: https://doi.org/10.1101/2021.08.14.21262042; this version posted August 20, 2021. The copyright holder for this preprint

manufacturer (SARS-CoV-2-IGRA, Euroimmun AG) (28). The SARS-CoV-2-specific activities of subtypes of both the CD4+ and the CD8+ T cell populations can be assessed by this method, although the highest response is from CD4+ subpopulations $(29,30)$.

For comparisons of Ig titers at two time points, either unpaired (when values of all participants were analyzed) or paired Student's t-tests (for analysis of values from same participants at two times points) were used for statistical analyzes. Curve fit analysis of IGRA as a function of Ig titers was performed with a confidence interval of $95 \%$ and automatic outlier elimination $(6 / 70$ values were excluded).

The study was approved by ethics committee of the Danube Private University, in accordance with local and national guidelines.

\section{Results and discussion}

\section{Cohort description}

In February 2021, 552/1404 (39.3\%) inhabitants of Weißenkirchen participated in a voluntary blood draw to have their serum tested. $54.3 \%$ of our cohort was female, the mean age was 48.6 years, and the mean BMI was 25.9 (Table 1). Inhabitants were invited to participate in our study through a public call, with no restrictions imposed. 363 subjects had participated in our previous study in June 2020 (26), enabling longitudinal analyses within this subgroup. 50.6\% of this subgroup was female, the mean age was 49.2 years, and the mean BMI was 26.1 (Table 1).

Blood was used for the determination of serum levels of IgG and IgA antibodies, specific for the SARS-CoV-2 spike protein. For a subgroup of participants with IgG/IgA levels above threshold $(\mathrm{N}=78)$, $\mathrm{T}$ cell activity was determined through quantification of interferon $\gamma$ release (IGRA) by $\mathrm{T}$ cells, activated by a SARS-CoV-2-specific peptide mix.

\section{Prevalence of seroconversion}

In our previous study (June 2020), we measured in a different cohort from Weißenkirchen and surrounding communities that $8.5 \%$ were $\operatorname{IgG}$ positive, $9.0 \%$ were $\operatorname{IgA}$ positive, and $5.7 \%$ were both IgG and IgA positive (26). In the current study, our measurements for February 2021 indicated that $25.0 \%(138 / 552)$ of participants from Weißenkirchen were positive for IgG values, $23.6 \%(130 / 552)$ of participants were positive for IgA values, and 19.7\% (109/552) were positive for both IgG and IgA (Table 1). The slight incongruence of percentage of seroconversion in the cohort of June 2020 in table 1 one compared with the published data (26) stems from the fact that in table 1 only those participants are represented who donated blood on both dates and more likely were infected. The presented data from June 2020 and February 2021 cannot be directly 
compared due to different cohort compositions after the first and the second peak of the pandemic. In addition, they cannot easily be extrapolated to the total population of the township, since most probably there was a recruitment bias in our study and people who suspected that they either had been infected with SARS-CoV-2 or had been in contact with COVID-19 patients preferentially enrolled. Nevertheless, our data show that Weißenkirchen was heavily affected by both peaks of the pandemic, but in February 2021 was still far ahead from reaching natural herd immunity, supporting the need for the current extensive vaccination programs.

In February 2021, 10.9\% (60/552) of participants stated in the questionnaire having had a prior SARS-CoV-2 positive PCR test, and for $53(88 \%)$ of them, seroconversion could be detected through IgG or IgA positivity. As the incidence of seroconversion of $23.6-25.0 \%$ was markedly higher at that time point as predicted from the positive PCR tests, our data hint towards a significantly higher prevalence of SARS-CoV-2 positive people in this Austrian hotspot than officially recorded. This high level of undetected cases is in line with other reports from Austria (31).

\section{$\underline{\text { SARS-CoV-2-specific IgG and IgA levels and persistence }}$}

We previously observed that both IgG and IgA seroprevalence remained very stable in October 2020, i.e., four months after our initial study in June 2020 (27). In the current study, we were interested in the seroprevalence eight months after our initial study. The 363 participants, who donated blood both in June 2020 and February 2021, allowed us to determine the persistence of serum IgG and IgA antibodies, although the time point of infection or disease onset could not be determined in our cohort.

In June 2020, 11.6\% (42/363) of participants had IgG levels above the cutoff (of $0.8 \mathrm{RU}$ ), compared to 23.6\% (86/363) in February 2021 (Fig. 1A). Similarly, in June 2020, 12.1\% (44/363) of persons had positive IgA levels, compared to 22.8\% (83/363) in February 2021. Thus, the proportion of people with SARS-CoV-2-specific antibodies approximately doubled within the eight months between June 2020 and February 2021, supporting our assumption that Weißenkirchen was heavily affected by the second peak of the pandemic.

Next, we plotted the semiquantitative IgG and IgA titers for the 363 donors at both time points. For IgG titers, the mean values of the titers significantly increased from $0.69 \mathrm{RU}(+/-0.08 \mathrm{RU})$ to $0.96 \mathrm{RU}(+/-0.1 \mathrm{RU})$ (two-tailed t-test, $\mathrm{p}=0.002$ ) (Fig. 1B). IgA levels were also higher in February 2021, with $0.74 \mathrm{RU}$ (+/-0.08 RU) compared to $0.48 \mathrm{RU}$ (+/- $0.06 \mathrm{RU})$ in June 2021 $(p<0.0001)$ (Fig. 1C). These data demonstrate the significant increase of antibody-based immune responses from June 2020 to February 2021 in the subgroup tested at both time points. 
medRxiv preprint doi: https://doi.org/10.1101/2021.08.14.21262042; this version posted August 20, 2021. The copyright holder for this preprint

However, it must be noted that our conclusions about the cohort are limited by the absence of a specific date of disease onset.

Next, we were interested in determining whether this increase in IgG and IgA serum concentration in February 2021 was mainly due to new infections or to a combination of new infections plus stable or increasing antibody titers in SARS-CoV-2 participants from June 2020. Therefore, we restricted the plotting of the Ig values to participants that had been tested positive in June 2020 for IgG (42) and IgA (44), respectively. We found that IgG levels were significantly reduced by $24 \%$ from the first measurement in June 2020 to the recent measurement in February 2021 from 5.24 RU (+/- $0.60 \mathrm{RU})$ to $3.97 \mathrm{RU}(+/-0.57 \mathrm{RU})(\mathrm{p}=0.0007)$ (Fig. 1D). IgA levels remained stable between time points of data collection (Fig. 1E). When the same data set is plotted with connecting lines between values from the same individuals, one can observe that almost all IgG values (39/42) are reduced in February 2021 when compared to June 2020 (Fig. 1F, p < 0.0001). For IgA values, most values (33/47) are reduced or stable, whereas 30\% $(14 / 47)$ of the values are elevated in comparison to the first measurement in June 2020. To illustrate IgA titer development, we split the data into three bins: IgA levels $>2.5$; IgA levels 1.52.49; IgA levels 1-1.49 (Fig. 1G, from left to right). In most participants with low IgA levels in June 2020, titers decreased between time points, while in participants with moderate to high IgA levels in June 2020, however, titers increased further. One possible explanation for the phenomenon might be an underlying re-infection, which, while rare, has been shown for $0.65 \%$ in a large longitudinal population-level observational study (32).

These data indicate that the increase in total $\mathrm{IgG}$ and $\operatorname{IgA}$ titers from the 363 persons participating in both the June 2020 and February 2021 studies (see Fig 1B, 1C) mainly stems from new infections, although the time points of disease onset could not be identified. However, even though IgG levels of participants that had already seroconverted in June 2020 (or before) are significantly reduced in February 2021, they remain well above the threshold of the applied ELSIA test over the time course of eight months. Taken together, our data show that both IgG and IgA seroprevalence persistent between June 2020 and February 2021.

\section{The extent of the $\mathrm{T}$ cell response does not significantly correlate with either IgG or IgA levels}

To ascertain if SARS-CoV-2-specific immunoglobulin levels and $\mathrm{T}$ cell responses correlate, we tested the blood of a subgroup of 78 participants for $\mathrm{T}$ cell activities. $\mathrm{T}$ cell activities were determined for participants with IgG/IgA levels above threshold at either time point, by measuring interferon $\gamma$ release (IGRA) by $\mathrm{T}$ cells activated by a SARS-CoV-2-specific peptide 
medRxiv preprint doi: https://doi.org/10.1101/2021.08.14.21262042; this version posted August 20, 2021. The copyright holder for this preprint

mix. Six of the 78 samples (7.7\%) showed an IGRA response that was higher than the maximal value of the standard curve and therefore had to be excluded in the plot. From the remaining participants, 64\% (50/78) showed SARS-CoV-2-specific T cell activation, 58\% (45/78) demonstrated SARS-CoV-2-specific IgG, 58\% (45/78) showed SARS-CoV-2-specific IgA levels, and 44\% (34/78) showed all three hallmarks of adaptive immunity (Fig. 2). The latter group should benefit from a comprehensive immune response, including humoral and cellular adaptive immunity.

When comparing SARS-CoV-2-specific $\mathrm{T}$ cell activities with SARS-CoV-2-specific humoral response, in 86\% (43/50) of persons with active T cells, SARS-CoV-2-specific IgG levels could be detected (Fig. 2). In contrast, only 74\% (37/50) of persons with active T cells showed elevated levels SARS-CoV-2-specific IgA. To test whether SARS-CoV-2-specific T cell activities and levels of IgG and IgA may be correlated, we plotted IgG or IgA titers against the response of the interferon- $\gamma$-release assay (IGRA). When we plotted the IgG values of the remaining samples against the corresponding IGRA values, we could not find a significant correlation with the IGRA response, albeit a trend could be observed with a moderate $\mathrm{R}^{2}$ of 0.68 (Fig. 3A). In contrast, clearly no correlation was found for IgA values from the same blood samples (Fig. 3B). Although most participants with SARS-CoV-2-specific humoral responses show virus-specific $\mathrm{T}$ cell activities, the magnitudes of both responses do not significantly correlate. Thus, for a comprehensive assessment, it is advised to test both the $\mathrm{T}$ cell response and the seroprevalence, including IgG and IgA.

Measuring SARS-CoV-2-specific IgG alone does not give a comprehensive view on immune response

One important finding of our study is that IgA titers remain more stable than IgG titers; the latter are supposed to be the carriers of long-term immune response. The literature on antibody persistence is ambiguous. For example, one study showed that IgAs against $\mathrm{N}$ protein and the receptor binding domain (RBD) of the S protein wane within a period of four weeks (2). Our findings are consistent with data by Dan et al. who showed that S and RBD IgGs exhibited similar kinetics and were shorter lived than S IgAs. Both antibody types were still largely present in most of their subjects six to eight months after infection (5). Wang et al. further showed that IgG levels start to decline three months post symptom onset (33). Differences in the literature can be in part explained by the different antibody targeting specificities, which may also entail different stabilities, but also by the different sensitivities of the applied test systems. 
medRxiv preprint doi: https://doi.org/10.1101/2021.08.14.21262042; this version posted August 20, 2021. The copyright holder for this preprint

Although most participants of our study with elevated SARS-CoV-2-specific antibodies show specific $T$ cell activities, we did not detect a significant correlation between the magnitudes of the humoral and $\mathrm{T}$ cell responses at a given time point. Few studies test the same subjects for IgGs, IgAs and the $\mathrm{T}$ cell response to ascertain an inter-relationship between the different immune markers. In a relatively small study with twenty subjects with mainly mild COVID-19 symptoms, a clear correlation between RBD IgGs and S-specific $\mathrm{CD}^{+} \mathrm{T}$ cell response was determined, and a similar correlation was found between anti-spike IgA titers and spike-specific CD4 ${ }^{+} \mathrm{T}$ cells (34). Here, we did not detect a correlation between S-specific IgA and IGRA, possibly due to differences in assay technicalities as well as differences in antibody specificities. Another study found a moderate correlation between S-specific IgG antibodies and $\mathrm{T}$ cell responses (35). Dan et al. determined that the ratio between CD4 cell and RBD IgGs is stable over time, however the variation was large, impeding a conclusive statement (5). They also found higher S-specific IgG values in hospitalized cases, while their $\mathrm{T}$ cell memory was reduced. Our data pointing stems solely from non-hospitalized subjects and thus cannot be directly compared with the hospitalized patient group of Dan's study.

The major limitation of our study is the fact that we do not have reliable PCR test results for participants. Since this was a study with no recruitment restriction, participants self-reported previous SARS-CoV-2 infections or COVID-19 symptoms, but no PCR test was performed within our study. The percentage of patients with a known infection who do not become seropositive is low (36). As we restricted $\mathrm{T}$ cell analyses to a seropositive subgroup, however, we may have overseen a certain number of patients which could have shown a positive IGRA response. Furthermore, since we did not perform PCR tests, it is difficult to clearly determine the maximal period of Ig persistence in our cohort. If patients were seropositive in June, we can deduce antibody persistence of at least eight months (time between June 2020 and February 2021). Especially for patients who were infected during the first wave described in Lower Austria in February 2020, antibody persistence possibly may be extended to twelve months. Indeed, there may be a recruitment bias since people with known or suspected prior infection or prior contact with infected people, may have preferably enrolled in our study.

\section{Conclusion}

In our population study, we show evidence of a high and persistent prevalence of antibodies (both IgG and IgA). Although most participants with antibodies (76\%) demonstrate specific $\mathrm{T}$ cell activities (and vice versa), we could not find a significant correlation of the extent of $\mathrm{T}$ cell 
activation with the amount of antibodies. The quantitative determination of both markers of immunity is not useful for routine analyses, due to the increased complexity of $\mathrm{T}$ cell measurements. However, the analyses of antibodies cannot surrogate the measurement of $\mathrm{T}$ cell activities, which are predicted to markedly contribute to immunity against SARS-CoV-2. As most data sets on immunity after infection or vaccination rely on ( $\operatorname{IgG})$ antibody determination only, further studies will have to ascertain to what extent antibody levels can predict immunity. These analyses might be challenged by a broad dispersion within the human population concerning the reciprocal interaction between antibody and $\mathrm{T}$ cell activities.

\section{Acknowledgements}

We would like to thank district manager Markus Pöschl, managing director Manfred Türk, Dr. Hannes Winkler, Helene Winkler, Dr. Herwig Jamek and Dr. Julia Jamek (all Austrian Red Cross, district office Krems/Donau) and the entire Red Cross team for co-organization and taking the blood samples. This study was financed by internal funds of the Danube Private University.

\section{Author contributions}

MS and TS performed data cleaning and preparation for analysis. HR, DL, RJB, and OH analyzed the data. HR, RJB and DL wrote the manuscript. All authors contributed to revision of the article and approved the submitted version.

\section{Conflict of Interest}

The authors declare no conflicts of interest. 
medRxiv preprint doi: https://doi.org/10.1101/2021.08.14.21262042; this version posted August 20, 2021. The copyright holder for this preprint (which was not certified by peer review) is the author/funder, who has granted medRxiv a license to display the preprint in perpetuity.

\section{References}

1. Galipeau Y, Greig M, Liu G, Driedger M, Langlois MA. Humoral Responses and Serological Assays in SARS-CoV-2 Infections. Front Immunol. 2020;11:610688.

2. Sterlin D, Mathian A, Miyara M, Mohr A, Anna F, Claer L, et al. IgA dominates the early neutralizing antibody response to SARS-CoV-2. Sci Transl Med. 2021;13(577).

3. Wang Z, Lorenzi JCC, Muecksch F, Finkin S, Viant C, Gaebler C, et al. Enhanced SARS-CoV-2 neutralization by dimeric IgA. Sci Transl Med. 2021;13(577).

4. Roltgen K, Powell AE, Wirz OF, Stevens BA, Hogan CA, Najeeb J, et al. Defining the features and duration of antibody responses to SARS-CoV-2 infection associated with disease severity and outcome. Sci Immunol. 2020;5(54).

5. Dan JM, Mateus J, Kato Y, Hastie KM, Yu ED, Faliti CE, et al. Immunological memory to SARS-CoV-2 assessed for up to 8 months after infection. Science. 2021;371(6529).

6. Hartley GE, Edwards ESJ, Aui PM, Varese N, Stojanovic S, McMahon J, et al. Rapid generation of durable B cell memory to SARS-CoV-2 spike and nucleocapsid proteins in COVID-19 and convalescence. Sci Immunol. 2020;5(54).

7. Figueiredo-Campos P, Blankenhaus B, Mota C, Gomes A, Serrano M, Ariotti S, et al. Seroprevalence of anti-SARS-CoV-2 antibodies in COVID-19 patients and healthy volunteers up to 6 months post disease onset. Eur J Immunol. 2020;50(12):2025-40.

8. Gaebler C, Wang Z, Lorenzi JCC, Muecksch F, Finkin S, Tokuyama M, et al. Evolution of antibody immunity to SARS-CoV-2. Nature. 2021;591(7851):639-44.

9. Gudbjartsson DF, Norddahl GL, Melsted P, Gunnarsdottir K, Holm H, Eythorsson E, et al. Humoral Immune Response to SARS-CoV-2 in Iceland. N Engl J Med. 2020;383(18):1724-34.

10. Isho B, Abe KT, Zuo M, Jamal AJ, Rathod B, Wang JH, et al. Persistence of serum and saliva antibody responses to SARS-CoV-2 spike antigens in COVID-19 patients. Sci Immunol. 2020;5(52).

11. Iyer AS, Jones FK, Nodoushani A, Kelly M, Becker M, Slater D, et al. Persistence and decay of human antibody responses to the receptor binding domain of SARS-CoV-2 spike protein in COVID-19 patients. Sci Immunol. 2020;5(52).

12. Koutsakos M, Rowntree LC, Hensen L, Chua BY, van de Sandt CE, Habel JR, et al. Integrated immune dynamics define correlates of COVID-19 severity and antibody responses. Cell Rep Med. 2021;2(3):100208.

13. Seow J, Graham C, Merrick B, Acors S, Pickering S, Steel KJA, et al. Longitudinal observation and decline of neutralizing antibody responses in the three months following SARS-CoV-2 infection in humans. Nat Microbiol. 2020;5(12):1598-607.

14. Wheatley AK, Juno JA, Wang JJ, Selva KJ, Reynaldi A, Tan HX, et al. Evolution of immune responses to SARS-CoV-2 in mild-moderate COVID-19. Nat Commun. 2021;12(1):1162.

15. Crawford KHD, Dingens AS, Eguia R, Wolf CR, Wilcox N, Logue JK, et al. Dynamics of Neutralizing Antibody Titers in the Months After Severe Acute Respiratory Syndrome Coronavirus 2 Infection. J Infect Dis. 2021;223(2):197-205. 
medRxiv preprint doi: https://doi.org/10.1101/2021.08.14.21262042; this version posted August 20, 2021. The copyright holder for this preprint (which was not certified by peer review) is the author/funder, who has granted medRxiv a license to display the preprint in perpetuity. It is made available under a CC-BY-NC-ND 4.0 International license .

16. Schaffner A, Risch L, Weber M, Thiel S, Jungert K, Pichler M, et al. Sustained SARS-CoV-2 nucleocapsid antibody levels in nonsevere COVID-19: a populationbased study. Clin Chem Lab Med. 2020;59(2):e49-e51.

17. Orth-Holler D, Eigentler A, Stiasny K, Weseslindtner L, Most J. Kinetics of SARS-CoV-2 specific antibodies (IgM, IgA, IgG) in non-hospitalized patients four months following infection. J Infect. 2021;82(2):282-327.

18. Knies A, Ladage D, Braun RJ, Kimpel J, Schneider M. Persistence of humoral response upon SARS-CoV-2 infection. Rev Med Virol. 2021:e2272.

19. Post N, Eddy D, Huntley C, van Schalkwyk MC, Shrotri M, Leeman D, et al. Antibody response to SARS-CoV-2 infection in humans: A systematic review. PloS one. 2020;15(12):e0244126.

20. Sekine T, Perez-Potti A, Rivera-Ballesteros O, Stralin K, Gorin JB, Olsson A, et al. Robust T Cell Immunity in Convalescent Individuals with Asymptomatic or Mild COVID-19. Cell. 2020;183(1):158-68 e14.

21. Sette A, Crotty S. Adaptive immunity to SARS-CoV-2 and COVID-19. Cell. 2021;184(4):861-80.

22. Shrotri M, van Schalkwyk MCI, Post N, Eddy D, Huntley C, Leeman D, et al. T cell response to SARS-CoV-2 infection in humans: A systematic review. PLoS One. 2021;16(1):e0245532.

23. Tan AT, Linster M, Tan CW, Le Bert N, Chia WN, Kunasegaran K, et al. Early induction of functional SARS-CoV-2-specific $\mathrm{T}$ cells associates with rapid viral clearance and mild disease in COVID-19 patients. Cell Rep. 2021;34(6):108728.

24. Takahashi T, Iwasaki A. Sex differences in immune responses. Science. 2021;371(6527):347-8.

25. Peng Y, Mentzer AJ, Liu G, Yao X, Yin Z, Dong D, et al. Broad and strong memory CD4(+) and CD8(+) T cells induced by SARS-CoV-2 in UK convalescent individuals following COVID-19. Nat Immunol. 2020;21(11):1336-45.

26. Ladage D, Hoglinger Y, Ladage D, Adler C, Yalcin I, Harzer O, et al. SARS-CoV2-Specific Antibody Prevalence and Symptoms in a Local Austrian Population. Front Med (Lausanne). 2021;8:632942.

27. Ladage D, Rosgen D, Schreiner C, Ladage D, Adler C, Harzer O, et al. Persisting Antibody Response to SARS-CoV-2 in a Local Austrian Population. Front Med (Lausanne). 2021;8:653630.

28. Ladage D HO, Engel P, Winkler H, Braun RJ. Persisting adaptive immunity to SARS-CoV-2 in Lower Austria. medRxiv 2021031021253251. 2021.

29. Murugesan K, Jagannathan P, Pham TD, Pandey S, Bonilla HF, Jacobson K, et al. Interferon-gamma release assay for accurate detection of SARS-CoV-2 $\mathrm{T}$ cell response. Clin Infect Dis. 2020.

30. Petrone L, Petruccioli E, Vanini V, Cuzzi G, Najafi Fard S, Alonzi T, et al. A whole blood test to measure SARS-CoV-2-specific response in COVID-19 patients. Clin Microbiol Infect. 2021;27(2):286 e7- e13.

31. Martin Bicher CR, Günter Schneckenreither, Nadine Weibrecht, Christoph Urach, Melanie Zechmeister, Dominik Brunmeir, Wolfgang Huf, Niki Popper. Model Based Estimation of the SARS-CoV-2 Immunization Level in Austria and Consequences for Herd Immunity Effects. medRxiv 2021031021253251. 2021. 
medRxiv preprint doi: https://doi.org/10.1101/2021.08.14.21262042; this version posted August 20, 2021. The copyright holder for this preprint (which was not certified by peer review) is the author/funder, who has granted medRxiv a license to display the preprint in perpetuity.

It is made available under a CC-BY-NC-ND 4.0 International license .

32. Hansen CH, Michlmayr D, Gubbels SM, Molbak K, Ethelberg S. Assessment of protection against reinfection with SARS-CoV-2 among 4 million PCR-tested individuals in Denmark in 2020: a population-level observational study. Lancet. 2021;397(10280):1204-12.

33. Wang Y, Li J, Li H, Lei P, Shen G, Yang C. Persistence of SARS-CoV-2-specific antibodies in COVID-19 patients. Int Immunopharmacol. 2021;90:107271.

34. Grifoni A, Weiskopf D, Ramirez SI, Mateus J, Dan JM, Moderbacher CR, et al. Targets of T Cell Responses to SARS-CoV-2 Coronavirus in Humans with COVID-19 Disease and Unexposed Individuals. Cell. 2020;181(7):1489-501 e15.

35. Bilich T, Nelde A, Heitmann JS, Maringer Y, Roerden M, Bauer J, et al. T cell and antibody kinetics delineate SARS-CoV-2 peptides mediating long-term immune responses in COVID-19 convalescent individuals. Sci Transl Med. 2021;13(590).

36. Wajnberg A, Amanat F, Firpo A, Altman DR, Bailey MJ, Mansour M, et al. Robust neutralizing antibodies to SARS-CoV-2 infection persist for months. Science. 2020;370(6521):1227-30. 
medRxiv preprint doi: https://doi.org/10.1101/2021.08.14.21262042; this version posted August 20, 2021. The copyright holder for this preprint (which was not certified by peer review) is the author/funder, who has granted medRxiv a license to display the preprint in perpetuity.

It is made available under a CC-BY-NC-ND 4.0 International license .

\begin{tabular}{|l|l|l|}
\hline & $\begin{array}{l}\text { Febr 2021 (all } \\
\text { participants) }\end{array}$ & $\begin{array}{l}\text { Participants in June 2020 and } \\
\text { Febr 2021 }\end{array}$ \\
\hline Number of participants & 552 & 363 \\
\hline Female & $300(54.3 \%)$ & $184(50.6 \%)$ \\
\hline Age (mean +/- SEM) & $48.6(+/-0.8)$ & $47.4(+/-1.4)$ \\
\hline BMI (mean +/- SEM) & $25.9(+/-0.2)$ & $25.5(+/-0.4)$ \\
\hline IgG+ (>0.8 AU) & $138(25 \%)$ & $\begin{array}{l}\text { June 2020: } 42(11.6 \%) \\
\text { Febr. 2021: } 86(23.6 \%)\end{array}$ \\
\hline IgA+ (>0.8 AU) & $130(23.6 \%)$ & $\begin{array}{l}\text { June 2020: } 44(12.1 \%) \\
\text { Febr. 2021: } 83(22.8 \%)\end{array}$ \\
\hline IgG+ and IgA+ (>0.8 AU) & $109(19.7 \%)$ & $\begin{array}{l}\text { June 2020: } 29(7.9 \%) \\
\text { Febr. 2021: } 65(17.9 \%)\end{array}$ \\
\hline $\begin{array}{l}\text { IGRA SARS2+ (>100 } \\
\text { mU/mI) }\end{array}$ & $\begin{array}{l}\text { Febr. 2021: } 34 \\
\text { of 50 tested }\end{array}$ \\
\hline
\end{tabular}

Table 1: Cohort composition. * Participants with a previous positive test for SARS-CoV-2 (PCR or antigen) were selected for quantification of IGRA. 
medRxiv preprint doi: https://doi.org/10.1101/2021.08.14.21262042; this version posted August 20, 2021. The copyright holder for this preprint (which was not certified by peer review) is the author/funder, who has granted medRxiv a license to display the preprint in perpetuity.

It is made available under a CC-BY-NC-ND 4.0 International license .

A

\begin{tabular}{|l|l|l|l|l|}
\hline $\mathrm{N}=363$ & IgG+ & IgG- & IgA+ & IgA- \\
\hline June 2020 & 42 & 321 & 44 & 319 \\
\hline Febr 2021 & 85 & 278 & 81 & 282 \\
\hline
\end{tabular}

B

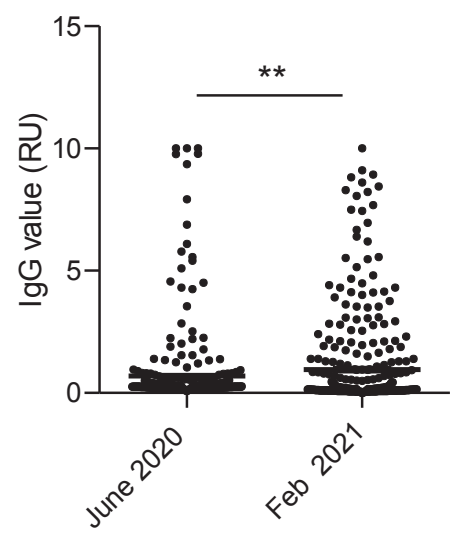

D

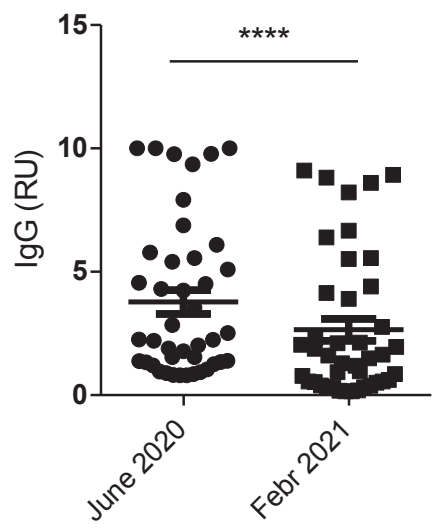

$\mathrm{F}$

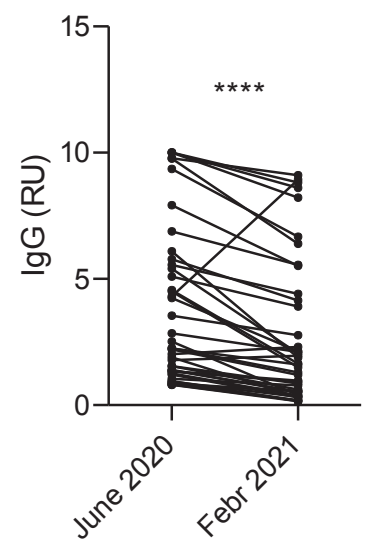

C

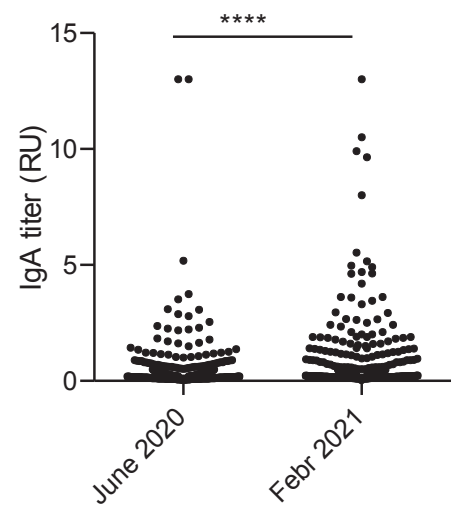

n.s.

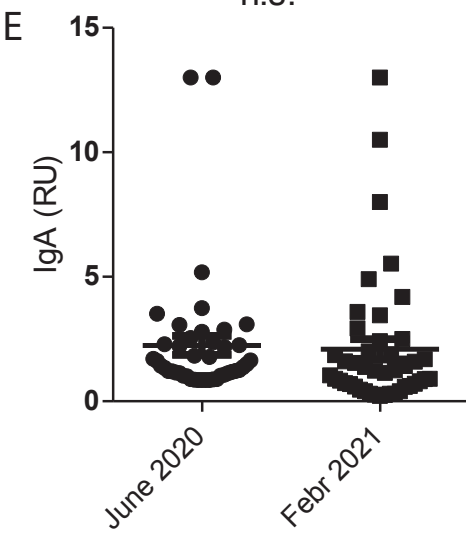

G

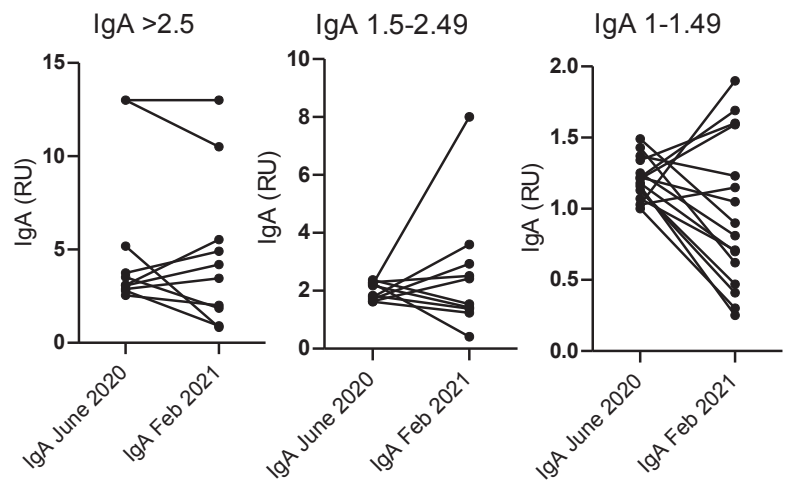

Fig. 1 Immunoglobulin titers measured in June 2020 and February 2021.

Table depicting numbers of particpiants with above-threshold titers for respective lgs (A). Vertical scatter plots of $\lg G(B)$ and $\lg A(C)$ titers derived from all particpants at two time points, and of $\lg G(D)$ and $\lg A(E)$ titers from participants who tested positive in June 2020. Plots depicting IgG $(F)$ and $\lg A(G)$ titers as in $(D, E)$ but with lines connecting data points of each individual. Statistical analysis was performed using student's t-test

$\left({ }^{* *} \mathrm{p}<0.01,{ }^{* * * *} \mathrm{p}<0.0001\right)$.

Fig. 1 
medRxiv preprint doi: https://doi.org/10.1101/2021.08.14.21262042; this version posted August 20, 2021. The copyright holder for this preprint (which was not certified by peer review) is the author/funder, who has granted medRxiv a license to display the preprint in perpetuity.

It is made available under a CC-BY-NC-ND 4.0 International license.

Total: $78(100 \%)$

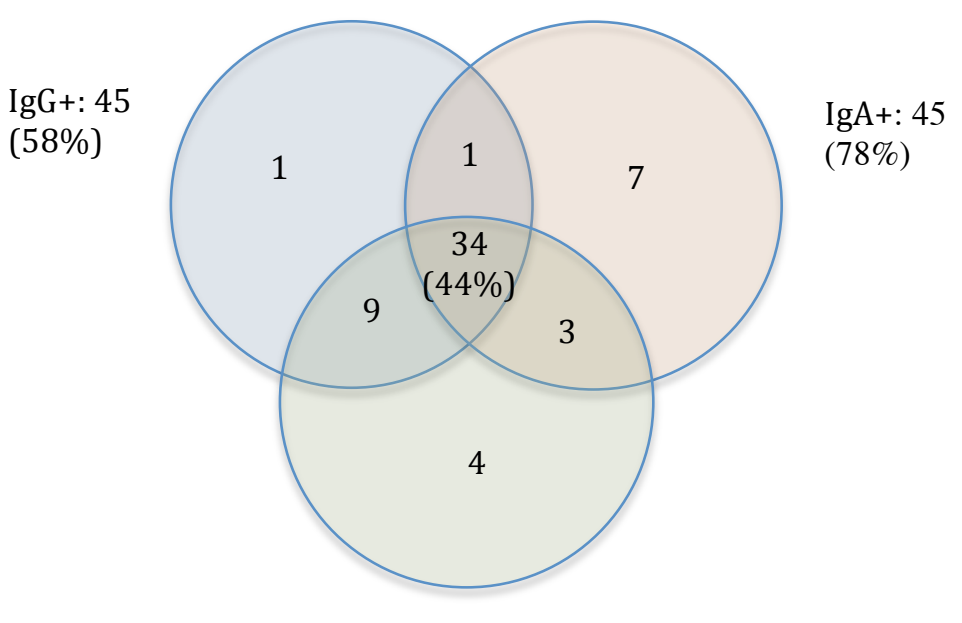

IGRA+: 50

$(64 \%)$

Fig. 2. Venn diagram depicting numbers of participants of the test cohort in February 2021 who had all three parameters (IgA, IgG and IGRA) measured ( $N=78)$.

Fig. 2 
A

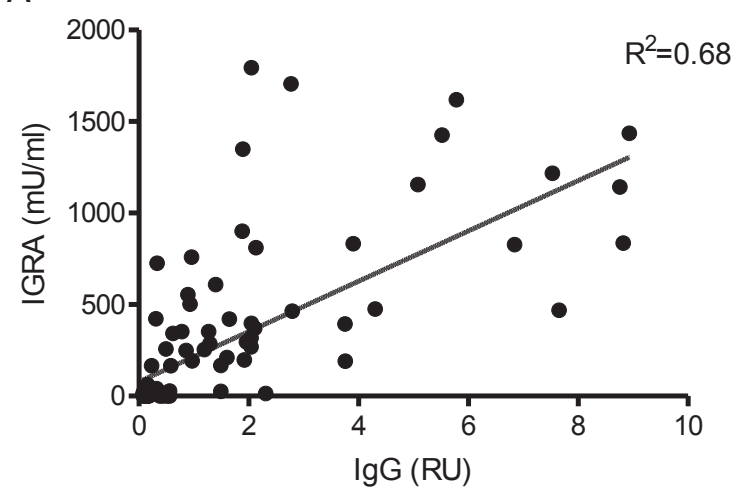

B

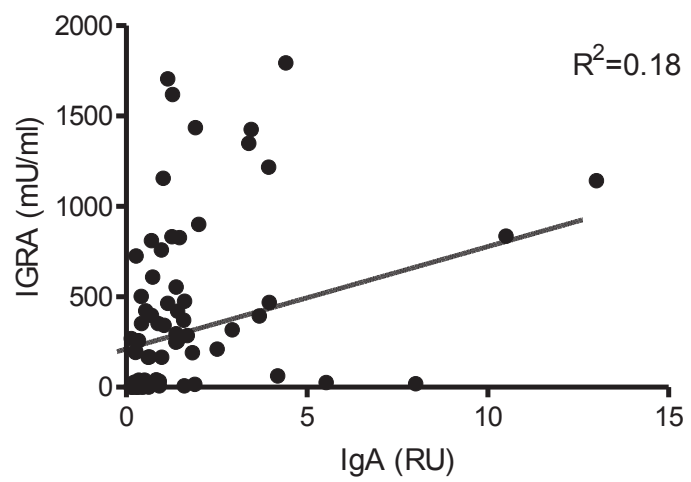

Fig. 3. Correlation of immunoglobulin titers with IGRA response.

Plot of interferon release as a function of $\lg G(A)$ and $\lg A(B)$ titers derived from serum taken in February 2021.

Fig. 3 